\title{
Mandatory Disclosure and Operational Risk: Evidence from Hedge Fund Registration
}

\author{
Stephen Brown, William Goetzmann, Bing Liang and Christopher Schwarz*
}

Journal of Finance, forthcoming

\begin{abstract}
Mandatory disclosure is a regulatory tool intended to allow market participants to assess operational risk. We examine the value of disclosure through the controversial SEC requirement, since overturned, which required major hedge funds to register as investment advisors and file Form ADV disclosures. Leverage and ownership structures suggest that lenders and equity investors were already aware of operational risk. However, operational risk does not mediate flow-performance relationships. Investors either lack this information or regard it as immaterial. These findings suggest that regulators should account for the endogenous production of information and the marginal benefit of disclosure to different investment clienteles.
\end{abstract}

JEL Classification: G2, K2

Keywords: Hedge funds, operational risk, SEC filing, Form ADV

\footnotetext{
*Stephen Brown is the David S. Loeb Professor of Finance at New York University Stern School of Business, William Goetzmann is the Edwin J. Beinecke Professor of Finance and Management, Yale School of Management, Bing Liang is Associate Professor of Finance, Isenberg School of Management, University of Massachusetts and Christopher Schwarz is a doctoral candidate in Finance, University of Massachusetts. We acknowledge the very extensive comments of the editor and referee, and thank Yong Chen, Mila Getmansky, Thomas Fraser, and seminar participants at Babson College, the CISDM 2006 Annual Conference, Erasmus University, the 2006 European Finance Association Meetings, Hong Kong University of Science and Technology, the 2007 INQUIRE Spring Seminar, Lancaster University, London Business School, Massey University, Monash University, National Sun Yat-Sen University, the New York Stock Exchange, the $9^{\text {th }}$ Conference of the European Central Bank - Centre for Financial Studies Research Network 2007, Oxford University, Rutgers University, Singapore Management University, the 20th Australasian Finance \& Banking Conference 2007, the University of Massachusetts at Amherst, the University of Melbourne, the University of North Carolina, the University of Sydney, the University of Vienna, and the 2007 Western Finance Association Meetings for useful comments. While this research was supported in part by a grant from INQUIRE UK and a grant from the BSI Gamma Foundation, it does not necessarily reflect the views of either organization. Please direct all email correspondence to bliang@som.umass.edu.
} 
MANDATORY DISCLOSURE is an important regulatory tool intended to allow market participants to assess manager risks without unnecessarily constraining manager actions. This trade-off between transparency and freedom of activity is particularly relevant for hedge funds, which often rely on proprietary models and positions. ${ }^{1}$ In the ongoing dialogue over the pros and cons of hedge fund activity, the U.S. Securities and Exchange Commission (SEC) in particular has tried to walk a fine line between allowing the invisible hand of the market to establish the level and type of disclosure demanded of investment managers, while at the same time seeking to require a minimum framework of transparency with respect to operational risk.

A recent failed attempt to bring hedge funds within the purview of SEC regulation affords an opportunity to test whether mandated disclosure - at least for one sector of the investment industry - has value as a public good or is simply costly and redundant. In this paper we test the potential value and materiality of operational risk and conflict of interest variables disclosed by a large number of hedge funds in February 2006. We find that operational risk indicators are conditionally correlated with conflict of interest variables, indicating a potential value of disclosing such conflicts to investors. Operational risk factors are also correlated with lower leverage and concentrated ownership, suggesting that the 2006 disclosure requirements may have been redundant for lenders and equity investors in hedge funds. In contrast, operational risk factors had no ex-post effect on the flow-performance relationship, suggesting that investors either lack this information or do not regard it as material. 
The results of our analysis provide a framework for the cost-benefit analysis of regulatory disclosure. Our findings suggest that any consideration of disclosure requirements should take into account the endogenous production of information within the industry, and the marginal benefit of required disclosure on different investment clienteles.

On December 2, 2004, the SEC adopted a new rule and rule amendments under the Investment Advisers Act of 1940 that would require hedge fund managers to register as investment advisers by February 1, 2006. Prior to the new requirements, only a small number of managers, generally of large hedge funds, were required to be registered as investment advisers with the SEC. To comply with the new requirements, hedge fund managers were required to file Form ADV with the SEC and to comply with a variety of additional regulatory requirements. Form ADV is a regulatory filing that is required of all types of fund managers, including hedge fund managers, mutual fund managers, and separate account managers, that fall under the definition of "investment adviser" in the Investment Advisers Act. However, on June 23, 2006, the U.S. Court of Appeals for the District of Columbia Circuit vacated the rule changes that had required many newly registered hedge fund managers to register as investment advisers under the Investment Advisers Act. Since the rule changes were vacated, far fewer hedge fund managers have been required to register as investment advisors.

As a result, the February 2006 ADV filings by a large number of hedge fund managers present a rare opportunity to examine the fundamental question of whether such disclosure is necessary or warranted. Prior to February 2006, some hedge fund managers, particularly managers of large funds, had been registered. The February 2006 
filings, however, made a much larger and less biased sample available. The Form ADVs for this larger sample contain a wealth of information, previously unavailable for many managers, about fund characteristics such as potential conflicts of interest and past legal and regulatory problems. Both of these relate directly to the stated purpose of the disclosure, which includes "deterrence of fraud," "keeping unfit persons from using hedge funds to perpetrate fraud," "adoption of compliance controls," or more generally, the avoidance of operational risk. ${ }^{2}$

By relating the Form ADV disclosures to fund characteristics, we are able to obtain a quantifiable measure of operational risk that is distinct from market risk. We can then examine whether in fact the Form ADV filing requirement provides material information to investors seeking to mitigate this measure of operational risk. The alternative hypothesis is that the marketplace has already effectively disseminated this information through other means, ranging from networks of informal contacts to feebased due-diligence research services to investments in funds of hedge fund intermediaries that perform the due diligence on the investor's behalf. In other words, we can ask: are Form ADV filings simply redundant and expensive, or do they provide valuable, otherwise inaccessible information to participants in the market for hedge fund services, thereby helping them avoid investing in potentially fraudulent firms?

This analysis provides interesting insight into the mechanics of the information disclosure hypothesis, which suggests that the market in other contexts rewards those firms that voluntarily submit to SEC disclosure requirements. ${ }^{3}$ Consistent with this argument, we find evidence that the information in the form has the potential to add value to the investor decision-making process. Hedge funds operated by managers filing Form 
ADV in 2006 had better past performance and had more assets than those operated by managers who did not file either because they were technically exempt from the filing requirement, or because they simply chose not to file. This result suggests that filing alone may be a potential signal of quality. ${ }^{4}$ In addition, we find a strong positive association between potential conflicts identified in the Form ADV filing and past legal and regulatory problems. Finally, through a canonical correlation analysis, we are able to establish a link between potential conflicts identified in Form ADV filings and operational risk characteristics in the Lipper TASS, Inc. (TASS) database. This allows us to establish a time series of operational risk for each fund in that database.

To examine whether Form ADV disclosure provides material information for investors concerned about operational risk, we use both hedge fund capital structure and the time series of investment flows. We hypothesize that equity and debt investors in hedge funds are able to distinguish among funds with differing potential for operational risk given the pre-ADV information available from research services and available databases. Consistent with this theory, we find that funds with past legal and regulatory problems have a more concentrated management structure and less average leverage than their "nonproblem" counterparts. This suggests that some market participants, such as equity fund investors and prime brokers extending credit, are able to distinguish problem from nonproblem funds.

We next test the proposition that the fund investors themselves are able to distinguish problem from nonproblem funds. To do so, we use the well-known flowperformance relationship. All things being equal, the information redundancy hypothesis implies that problem funds with good performance should experience lower net inflows 
than nonproblem funds with good performance. We find no evidence that this is so. Taken together, these results suggest that the evidence relating to the information disclosure hypothesis is mixed. Financial institutions and well-informed investors may already have the information contained in the Form ADV filing through the normal process of due diligence. Individual investors, however, may not have access to this information. This supports the argument that hedge fund disclosure may help level the informational playing field. On the other hand, we cannot exclude the possibility that these investors have access to this information and choose not to act on it. The bottom line is that mandatory disclosure of operational risk factors has the potential to benefit smaller investors, but, to the extent it shifts the due diligence costs (and compliance risk) from the existing information providers to the hedge funds themselves, it may or may not benefit larger investors.

Although the role of regulation in the investment industry is our primary focus, the empirical analysis also yields other interesting results. The premise of mandated information disclosure is that it helps to mitigate the fundamental problem of agency. We find evidence that agency issues are potentially important determinants of hedge fund performance and hedge fund capital structure.

The rest of the paper is organized as follows. Section I describes the ADV filing and reviews literature on operational risk. Section II describes the data from the SEC and TASS. Section III presents the testing hypothesis and the empirical results. Finally, Section IV concludes with a summary of our major findings. 


\section{Form ADV, Operational Risk, and Related Research}

The 2004 SEC investment adviser rule amendments referred to above required, among other things, that any hedge fund manager based in the United States with more than 14 clients, assets of at least $\$ 25$ million, and a lockup period of less than two years, ${ }^{5}$ as well as any internationally based fund with at least 14 U.S.-based investors, file Form ADVwith the $\mathrm{SEC}^{6}$. Form ADV is the same form used by all investment advisers. It contains information about potential conflicts of interest, both internal and external, any past regulatory or legal problems of both the hedge fund management company and any of its related advisors, and a wealth of specific ownership data. Prior to the 2004 rule changes, a smaller set of managers, mostly large hedge funds, were required to be registered as investment advisers with the SEC. ${ }^{7}$ These rule changes were strongly opposed by hedge fund managers, who argued that completing the 35-page form was unnecessarily costly and burdensome. ${ }^{8}$

Although onerous, Form ADV requests information that is potentially highly relevant to assessing the operational risk of the investment manager. The International Association of Financial Engineers defines operational risk as "losses caused by problems with people, processes, technology, or external events."9 More specifically, these include the risks of failure of the internal operational, control, and accounting systems, failure of the compliance and internal audit systems, and failure of personnel oversight systems, that is, employee fraud and misconduct. For example, losses due to rogue traders (e.g., Barings, National Australia Bank, Allied Irish Bank, and Société Générale ${ }^{10}$ ) and failures due to management fraud (e.g., Enron) and reputational injury such as the 2004 mutual fund timing scandal (e.g., Putnam) can all be thought of as 
operational risk events. These are distinct from market risk events such as Long Term Capital Management's failure due to credit exposure. Market risks are presumably measurable using quantitative risk models while operational risk has no direct numerical proxy. The challenge is to quantify this factor. Practitioner studies reveal that half of all hedge fund failures occur through operational risk events rather than taking excessive market risk (and losing). ${ }^{11}$

Operational risk assessment often relies upon intangible variables. Assessing personnel risk is perhaps the most difficult. Historical behavior and current opportunity are both potentially important inputs that enter into this assessment. Past manager behavior may include previous fiduciary decisions, as well as previous legal and regulatory actions taken against the manager, and any other variable that might be correlated with the propensity to make future illegal or unethical decisions in favor of one's own interests at the expense of a client, partner, or lender. While such tendencies are, of course, partly manageable within an organization through internal control and external compliance procedures, the risk of individual fraud is likely to increase with opportunity. In particular, as potential conflicts of interests between manager and investor increase, operational risk increases as well, holding control and compliance constant. Thus, although the questions in Form ADV might seem unduly personal and burdensome to some, they reflect the fact that measurement and assessment of operational risk, particularly risk centered on human intent and tendencies to act unethically or illegally, is difficult. ${ }^{12}$ In particular, Form ADV requires disclosure of past criminal charges against management personnel, including the nature, severity, and disposition of past charges. It also requires disclosure of past regulatory actions taken against the firm or its personnel, 
including the regulatory body and the nature of the sanction. It also requires disclosure of past civil judicial action, past bond action, and past arbitration relating to the firm. While none of these variables in isolation captures personnel-related operational risk, together they presumably provide evidence of past adverse behavior by the firm or by those the firm currently employs.

Another key set of variables we study in this paper helps to address conflicts of interest. This issue has been the subject of considerable research in the setting of investment banking. Dugar and Nathan (1995) and Michaely and Womack (1999), among others, have examined how investment banking conflicts affect stock analyst recommendations. They find that analysts' clients are more likely to receive positive coverage. In contrast, Lin and McNichols (1998) find no difference between analysts' recommendations when comparing client and non-client groups. Gompers and Lerner (1999) find little evidence of conflict of interest in the venture capital industry; the investment bank's affiliation to the public offering has no negative impact on the initial offering's performance.

A number of variables relating to potential conflicts of interest are required by Form ADV. In particular, the form asks whether any employee or entity controlled by the firm is affiliated with another type of financial institution such as a broker-dealer, mutual fund, or limited partnership. It asks about participation in clients' transactions, including proprietary interest in transactions, sales interest in transactions, brokerage discretion, and custody of client assets. In each of these cases, the potential exists for the manager to influence client decisions, or make decisions on the client's behalf that benefit the manager at the expense of the client. 
Another set of variables we examine in this paper relates to the ownership and governance structure of the hedge fund. Most of the current research on this relationship focuses on the mutual fund industry, where such information is readily accessible. Cremers (2006) find that mutual funds with high director share ownership perform better. Ding and Wermers (2006) find that the ratio of independent directors on mutual fund boards predicts out-of-sample performance. Khorana and Servaes (2007) find that out-ofsample performance is correlated with managerial ownership. Although there is widespread belief in the hedge fund industry that the size of the managerial stake in the fund is a potential proxy for good governance, such information is not generally available from hedge fund information vendors and no academic study to our knowledge has been able to empirically examine this issue. Form ADV requires detailed information both about direct ownership of the firm and indirect ownership of the firm.

\section{Data}

We obtain data for this study from two sources. The first is the TASS database. We use the February 2006 TASS data to match management companies with the SEC Form ADV filings. The TASS database contains information on 4,019 live hedge funds and 2,491 defunct hedge funds, along with their management companies. Data on individual hedge funds include their returns, assets (in most cases), lockup period, subscription and redemption periods, indication of a high water mark, and other characteristic data. TASS files also include the management company name and address. In addition to the February 2006 TASS data set, we also use eight previous TASS data 
sets. These nine data sets together cover the 1998 to 2006 period, and allow us to capture changes in fund characteristic data over time.

The second major source of data is the SEC investment adviser website. ${ }^{13}$ Each Form ADV contains information on an investment adviser. The filing consists of 12 items and also includes at least three schedules. ${ }^{14}$ Items 1 through 6 contain descriptive information on the firm, including its address, structure, number of employees in various positions, and a breakdown of investor types. Items 7 and 8 look at potential conflicts of interest of the firm. Item 9 examines the custody of various assets while Item 10 looks at the control persons of the firm. Item 12 provides information to allow the SEC to examine the effect of the regulation on small businesses.

Item 11 is of particular interest as it identifies any "problems" its management or related advisory affiliates have, including felonies, investment-related misdemeanors, or Federal or state agency, SEC, Commodity Futures Trading Commission (CFTC), or selfregulatory issues. If the firm answers yes to any of the questions on Item 11, it must also file a Disclosure Reporting Page (DRP), which expands on the problem identified in Item 11. ${ }^{15}$ Schedule A includes the direct owners and executive officers of the firm, Schedule B lists the indirect owners of the firm, and Schedule D includes a list of other business locations, other locations of record, previously nonlisted control persons, and the limited partnerships in which the firm participates.

Form ADV data are downloaded directly from the SEC website and imported automatically into a useable data set. ${ }^{16}$ To identify Form ADVs belonging to hedge fund companies, a two-phase search is implemented. Using the management company information in TASS, we first search for the management company listed for each fund. ${ }^{17}$ 
If that search is unsuccessful, we then search for any unique names that appear in the fund's name. In a majority of cases, the company is identified using just the management company information. ${ }^{18}$ Note that since the requirement to register began on February 1, 2006, our searches only encompass the live database. To ensure matches, one fund listed in the TASS data set had to be matched to a fund listed on Form ADV. ${ }^{19}$

We identify 879 management companies out of 1,697 listed in TASS, or $51.8 \%$ of the TASS database. These management companies represent 2,299 (57.2\%) of the 4,019 live funds in the live TASS database. The unmatched TASS funds include funds with less than the $\$ 25$ million in assets ( $22 \%$ of unmatched funds), funds with lockups longer than two years (2\%), and foreign companies with fewer than 14 U.S. investors (73\%). ${ }^{20}$

$<$ Insert Table I about here $>$

Table I provides descriptive statistics for both the matched and live TASS databases as well as their differences. While the returns and standard deviations of the matched data set differ slightly, the Sharpe ratios of registered funds are significantly higher than those of the overall TASS data set. Skewness and kurtosis are also insignificantly different; however, the autocorrelation of matched funds is significantly higher, perhaps indicating more illiquid portfolios. ${ }^{21}$ The average size of the matched funds, as well as the average minimum investment amount, is also not significantly different between the matched and total TASS samples. Differences in high water mark and fees suggest that filing funds may be of higher quality than nonfiling funds. 


\section{Tests and Results}

\section{A. Defining "Problem” Funds}

In order to examine the relationship between conflict of interest variables and legal and regulatory problems, we first need to classify funds into "problem" and “nonproblem" categories. These are reported in Table II.

$<$ Insert Table II about here $>$

Problem funds are those whose management companies answered yes to any of the questions on Item 11 in Form ADV, while nonproblem funds answered no to all questions on Item 11. Problems covered on Item 11 of Form ADV include any past felony or financial-related misdemeanor charges or convictions. The form also includes questions concerning any SEC, CFTC, federal or state agency, or other regulatory disciplinary action as well as civil lawsuits. Of the 2,299 funds in our sample, 368 have management firms that answered yes to at least one question on Item 11, or approximately $16.0 \%$ of our sample. ${ }^{22}$ The percentage of funds with problems is not being driven by only a few management companies; of the 879 management companies, 126 , or $14.3 \%$, answered affirmatively to a question on Item 11 .

This incidence rate may seem high, but it is actually comparable to the entire ADV sample. Using all Form ADV data from the SEC website compiled by a third party company, we are able to determine the problem rate for the entire Form ADV universe. ${ }^{23}$ Out of 10,295 ADV registrations, 1,526 indicated some type of problem. This represents $14.8 \%$ of all Form ADVs, which is almost identical to the $14.3 \%$ of our hedge fund sample. This sheds a potentially useful perspective on the relative operational risks in the hedge fund industry compared to the larger investment management universe. In 
particular, this finding supports the contention by the hedge fund industry that its operational problems are no greater than those in other investment management businesses. ${ }^{24}$

Panel A of Table II examines the performance differences and fund characteristics between problem and nonproblem funds. There is no significant difference in terms of standard deviation or autocorrelation of returns; however, the mean return, Sharpe ratio, and appraisal ratio are significantly lower for funds with problems. ${ }^{25,}{ }^{26}$ Panel B focuses on external relationships that represent potential conflicts of interest. ${ }^{27}$ It reports the frequencies for questions such as whether the manager has a related broker/dealer, investment company, investment adviser commodities broker, bank or insurance company, or whether the manager is the sponsor of an LLP. The frequency with which problem funds answered yes to these questions is universally higher than for nonproblem funds. For example, while $73.9 \%$ of problem funds have a related Investment Adviser, only $41.6 \%$ of nonproblem funds have the same issue. A similar dispersion exists with respect to whether the firm has a related investment company-50.3\% versus $15.8 \%$ for problem and nonproblem funds, respectively. Note that all differences are significant at the $1 \%$ level.

Panel $\mathrm{C}$ focuses on internal potential conflicts of interest. The variable AgencyCrossTrans for example, asks whether a broker-dealer buys and sells broker clients' securities to advisory clients. ${ }^{28}$ Only $2.3 \%$ of nonproblem funds have this potential conflict of interest while over $30 \%$ of problem funds do. Recommending securities to clients in which a related party has some ownership interest (RecSecYouOwn) also has a large difference, with $25 \%$ more problem funds exhibiting 
this conflict. As in Panel B, all of the differences between problem and nonproblem funds are statistically significant at the $1 \%$ level. The striking result of Panels B and C is the strong relationship between legal and regulatory problems and various measures of internal and external conflicts of interest. Another conflict variable, OtherResearch, represents services obtained from a broker-dealer that the fund uses for its transactions. It is strongly significant, and suggests that the potential for conflicts of interest can lead to operational risk events, as measured by legal and regulatory problems. This may be due to an actual higher incidence of fraudulent activity by managers of problem funds, or alternatively, it could be due to the fact that the simple presence of apparent conflicts of interest attracts more regulatory scrutiny and litigation.

Panel D examines the ownership and capital structure differences between the two groups. Problem funds have a higher number of direct and controlling owners. ${ }^{29}$ Interestingly, the number of direct owners in the form of non-individual domestic entities (DirectDomestic) is higher for problem funds than it is for nonproblem funds. This implies that problem firms are more likely to be structured as a venture or partnership with another institution. It also has the effect of allowing owners to hide their names from the ownership list, although it does not exempt them from reporting. Finally, the $75 \%$ ownership variable, which is the percentage of owners who own $75 \%$ of the company, is larger for problem funds. Theoretical results suggest that fear of expropriation-one source of operational risk - will make the management more concentrated rather than less concentrated. ${ }^{30}$ These results are confirmed in our data.

Panel D also provides information about the debt of the firm. It is well established that external financing is more problematic where agency costs are extreme. Indeed, 
Harvey, Lins, and Roper (2004) argue that external debt has an important role to play as a governance mechanism in such circumstances. It is therefore not surprising to find that problem firms have lower leverage and less margin than nonproblem firms. We investigate this relationship in more detail below.

Given that an affirmative answer on Item 11 could reflect anything from involvement in a civil suit to conviction of a felony, it is useful to examine whether the type of offense makes a difference. Are the differences between problem and nonproblem funds driven by one specific type of violation? To address this question, we classify the responses on Item 11 into four groups. Group 1 includes managers who responded affirmatively to being charged or convicted of a felony or a finance-related misdemeanor. Group 2 includes managers who have had their rights to trade revoked at some time in the past. Group 3 includes managers with some form of regulatory violation, including a falsification or fabrication. Group 4 includes managers involved in a civil suit. These classifications are non-exclusionary; one manager may show up in all four categories. For the sake of brevity, the results of this analysis are not presented in table form; however, they clearly indicate that the differences between problem and nonproblem funds are not driven by a single category of violation. ${ }^{31}$

$<$ Insert Table III about here $>$

The frequency of association between affirmative responses to Item 11 on Form $\mathrm{ADV}$ and affirmative responses to potential conflicts is interesting, but this correlation is not a direct test of the determinants of problem versus nonproblem funds. For example, one important issue in Table II is that the differences between problem and non-problem funds may be driven by differences in style or fund type. For instance, perhaps funds-of- 
funds attract more regulatory scrutiny, or have a different capital structure simply because their business is different than that of direct managers. Table III reports the results of a probit estimation with the dependent variable being one if the fund is a problem fund and zero if the fund is a nonproblem fund. All models in the estimation include style dummies (unreported) to control for style differences. Model 1 includes only the manager and fund characteristic variables. Size is not significant, but the lack of a high water mark and lower incentive fees are related to a fund having a problem. The association between past problems and lower incentive fees is interesting in the context of the redundancy hypothesis because it might indicate that the market rationally incorporates the information about the fund's past problems and requires compensation for future operational risk in the form of lower fees. This relationship is not driven by the fact that funds-of-funds have lower fees. One of the style categories used for control purposes in the probit is the fund-of-fund classification.

Model 2 adds the first operational risk variable. The relationship variable is one if the fund has one of the external relationship conflicts of interest listed in Table II, and zero otherwise. The variable RecSecYouOwn is one if the fund recommends securities in which a related party has an ownership interest, BuySellYourOwn is one if the company buys and sells between itself and clients, and OtherResearch is one if the fund uses external research from the same broker that executes its trades. The coefficients on all of these variables are large, positive, and statistically significant, indicating a positive relationship between potential conflicts of interest and legal or regulatory problems.

Model 3 adds two ownership variables to the model and exchanges the AgencyCrossTrans variable for the BuySellYourOwn variable, where AgencyCrossTrans 
is one if the fund buys and sells broker clients' securities to advisory clients. These two variables are highly correlated, and unreported results indicate that the AgencyCrossTrans variable dominates the BuySellYourOwn variable. The $75 \%$ ownership variable is the percentage of direct owners who own at least $75 \%$ of the company. If there is only one owner, the percentage is $100 \%$, versus $0 \%$ for a company with no large owner. The DirectDomestic variable is the number of domestic entities listed as direct owners.

The AgencyCrossTrans variable is highly significant and positive, which again indicates internal conflicts of interest are related to fund problems. The two ownership variables are also positive and significant. Funds with concentrated management are more likely to be problem funds, and funds with more domestic corporations listed as owners are more likely to be problem funds. In the context of the redundancy hypothesis, this suggests that it may be difficult to find large equity partners to take a significant stake if you have a checkered legal and regulatory past. ${ }^{32}$ This finding may be useful in future studies of ownership structure and investment performance, because it implies that the capital structure of investment partnerships is likely to be endogenously determined, not only by the technology it employs and the markets in which it trades, but also by the exposure of the firm to operational risk.

One might ask whether the results in the table are affected by survival bias. Previous literature documents a significant failure rate and survivorship bias in hedge fund returns (see Fung and Hsieh $(2000,2002)$ and Liang (2000)). Because the filing requirement for Form ADV and our data from TASS are from the same period of time, only live funds filed ADVs. To overcome this limitation, we supplement our original data 
set with the TASS data set from February 2005 in the hope that some funds filed early or voluntarily. We examine which funds from the Live database in February 2005 moved to the Defunct database from our February 2006 data set. After excluding funds with no management information in either data set, we find 126 funds died at some point during that year. While the sample size is small with only 46 matched funds from TASS ( 8 problem and 38 nonproblem), and significance levels are thus lower, the results for this select sample of defunct funds are substantially the same as for the broader sample. ${ }^{33}$

For robustness, we also perform the same tests on other subsamples. We estimate the probit on each of the four subcategories of problems identified above. These give weaker but quantitatively similar results. We remove managers with a large number of funds to verify that the results are not driven by a few large managers. They are not. We also remove managers with affiliated mutual fund companies to see if this has an impact on the results. For this sample, most of the documented relationships between conflicts and problems in Table III are quantitatively unaffected, although the differences in ownership structure are attenuated, as expected.

\section{B. Leverage and Operational Risk}

One test of the redundancy hypothesis is whether financial institutions such as prime brokers are able to distinguish between funds with higher and lower operational risk. To examine this, we explore differences in the leverage of problem and nonproblem funds. In Table II, we note a significantly different frequency in the reported use of leverage by problem and nonproblem funds. This zero-one variable does not take into account the degree of leverage, however, nor does it control for fund style. Given the 
wide disparity in the market risk of different hedge fund styles, this control is crucial. In particular, funds-of-funds are less likely to employ leverage, and more likely to be problem funds.

\section{$<$ Insert Table IV about here $>$}

Table IV examines the difference in three leverage measures for problem and nonproblem funds. The first, Leveraged, uses a zero-one variable reported by TASS as the measure of leverage. The second, Avg. Leverage, is the average fund leverage reported by TASS. The third, Maximum Leverage, is the maximum leverage of the fund reported by TASS. The test is applied to all funds in the matched sample, then to a subset that excludes funds-of-funds, and finally to a set for which the top $5 \%$ in terms of leverage are winsorized. Notice that the difference in the zero-one leverage variable is largely explained by funds-of-funds. Once these are excluded from the analysis, the leveraged variable is insignificant, but differences in average leverage and maximum leverage are both significant at traditional confidence levels. Winsorizing at the 5\% level of leverage shows that the significance is not driven by outliers. ${ }^{34}$

Table V shows how leverage differs by fund style. The consistency of the differences in average leverage across different fund styles is striking. Only one category (equity market neutral) has significantly higher average leverage for problem funds than for nonproblem funds. In all other categories except for global macro (with less than $1 \%$ of the problem cases) the average leverage of problem funds is lower.

$<$ Insert Table $\mathrm{V}$ about here $>$ 


\section{Performance and Operational Risk}

Up to this point, we document strong cross-sectional relationships among variables disclosed in Form ADV by hedge funds, and model the likelihood of legal and regulatory problems as a function of incentives, conflict of interest variables, and ownership structure. These analyses tell us little, however, about the actual returns to investment.

Table VI reports the result of a regression in which the fund's appraisal ratio is the dependent variable, and the set of explanatory variables includes those identified in the probit as determinants of legal or regulatory problems. As with the probit model, style dummies are included to control for style differences. As described earlier, appraisal ratios are computed using the funds' TASS style index returns, and the top and bottom $1 \%$ of appraisal ratios are winsorized to control for outliers. Clustered standard errors are used to correct for within-management company return correlation. ${ }^{35}$ Variables that have been previously found to be related to returns are also used for control purposes; fund size (LogAssets), the standard deviation of fund returns (StdDev), and Onshore (one if the fund is based in the U.S., and zero otherwise) are used as controls and a base specification in Model 1. Fund performance is positively related to all of these variables. Model 2 adds management and fund quality variables as well as the relationship variable. $^{36}$

$<$ Insert Table VI about here $>$

We see that the relationship variable, which is indicative of a potential external conflict of interest, is negative but insignificant. The last model adds ownership variables while continuing to use the same set of control variables. The addition of a domestic 
entity as a direct owner does not have a significant impact on performance. However, the more concentrated a fund's management, the lower the performance. Both of these variables may indicate a lack of management oversight, an additional layer of protection in case of fraud, or the attempt of management to hide the background of certain owners. Overall, operational risk, as measured by conflicts of interest and management structure, has some negative effect on performance.

One strong argument to justify the use of related entities for transactions and internal conflicts is that these provide a means to reduce costs. Although affiliates and multiple managerial responsibilities for clients may represent potential conflicts of interest, when used by ethical managers with good operational risk controls they may alternatively represent a benefit to investors. To examine this issue, we split the data into problem and nonproblem groups and re-run the model similar to Model 3 in Table VI. Style dummies are included to control for style differences and appraisal ratios are computed as before. A Chow test reveals that the results reported in Table VII are significantly different at the $1 \%$ level. ${ }^{37}$

\section{$<$ Insert Table VII about here $>$}

As a robustness check we examine the extent to which fund characteristics can explain the difference between problem fund returns and the returns on a matched sample of nonproblem funds. ${ }^{38}$ The results are qualitatively similar to the appraisal ratio results. The relationship variable is as significant as before, but we alse see that concentrated ownership leads to a significant reduction in performance, as does high incentive fees. ${ }^{39}$

Agency theory also makes predictions about the effect of ownership concentration on performance. Here, a simple linear model may be insufficient to capture predicted 
effects. Having a large shareholder with a significant stake in a publicly traded firm provides benefits to smaller shareholders due to coat-tail effects. However, if the shareholder is big enough, he or she is able to enjoy all the benefits of control. ${ }^{40}$ Since hedge funds are not organized like public corporations, predictions about the sign of the coefficient on ownership concentration are not clear. We might conjecture that having a single controlling owner leaves fewer checks on adverse behavior by other owners. On the other hand, reputational effects might cause such a major stakeholder to act in shareholders' best interests. As with the literature on the ownership structure of public corporations, the ownership structure is endogenously determined. Further, as we find above, endogenous factors influencing capital choice are likely to extend to the past regulatory and legal problems of the owner, as well as the markets traded and the technology developed by the firm.

In Table VII, both problem and nonproblem funds react the same way to the existence of an owner with more than $75 \%$ percent of firm equity, although the coefficient is only statistically significant for nonproblem funds. Concentrated ownership is related to lower performance for both samples. By sorting on the problem funds, we have already presumably proxied on fund management quality, and thus this particular variable loses its ability to predict performance with a sample of mostly poor quality funds. ${ }^{41}$

Taken together, these results provide some evidence that potential conflicts are not universally bad. They support the theory that related entities and overlapping services have the potential to provide benefits to clients. In other words, lack of constraints may be used either for good or ill, depending upon the quality and ethics of the manager. The 
results further suggest that a simple model of the effects of potential conflicts of interest may be insufficient, and that the interaction of these conflicts with legal and regulatory problems makes a difference.

\section{Observable Proxies for Operational Risk}

The results in Tables VI and VII indicate ADV proxies for operational risk are negatively related to historical performance. They thus represent an important possible forecasting variable for investors. Although these variables are not reported in publicly available databases prior to 2006, other variables are. Information such as fund style, size, age, types of investments and so forth could be obtained from leading data vendors such as TASS. In this section, we examine the potential for constructing an instrument for operational risk using these observed variables. This allows us to retrospectively examine the performance of "problem" funds. In addition, given the most recent court decision regarding SEC requirements for hedge fund managers to file Form ADV as part of the registration process, the instrument based on TASS or other databases may be a useful additional tool going forward with which to assess operational risk. Although many funds now have the option to deregister, it remains to be seen how many and what sort of funds choose to do so. Finally, the observable instrument allows us to examine the extent to which past publicly available information alone might have been able to capture operational risk.

To construct the instrument, we use a matched data set to perform a canonical correlation analysis using the Form ADV disclosures in 2006 together with TASS variables that have been observed over a number of years. ${ }^{42}$ We first identify TASS 
variables that prior research has shown to be associated with the probability of fund failure. We then define a linear combination of these variables that maximally correlate with the cross-section of Form ADV disclosures in February 2006 that match to the TASS sample. This linear combination is our univariate proxy for operational risk, or $\omega$ score. ${ }^{43}$ Finally, we use this linear combination to proxy for unobserved Form ADV information in the years prior to February 2006 using a time series of TASS fund characteristics.

$<$ Insert Table VIII about here $>$

Panel A of Table VIII reports the results of the canonical analysis. Average monthly returns from the previous year, monthly standard deviation from the previous year, size at the beginning of the period, fund age and whether or not the fund reports assets are included in the analysis, as these variables have been previously related to fund death (Liang (2000), Brown, Goetzmann and Park (2001), Getmansky, (2006)). The reported asset variable is a binary variable with a value of one if the fund reports assets and zero if it does not. Other characteristic data from TASS, which relate to fund quality, are also included.

The maximal correlation between a linear combination of TASS variables and Form ADV variables is 0.42 , significant at the $1 \%$ level. The Form ADV variables are almost all positively correlated with the canonical variable, indicating that a higher value has more operational risk. ${ }^{44}$ Higher returns, standard deviation, and incentive fee are all negatively correlated with the TASS canonical variable, indicating that these are negatively correlated with operational risk. This canonical variable, a linear combination 
of observed TASS variables calibrated to the February 2006 ADV disclosures, is our univariate proxy for operational risk, or $\omega$-score.

From 1994 to 2005, we compute the $\omega$-score each year using the raw coefficients from our original analysis on the matched sample. ${ }^{45}$ We then regress fund returns on this operational risk $\omega$-score and include unreported style dummies to control for style differences. ${ }^{46}$ We also control for market risk by estimating market betas for all funds each year and include the unreported betas in the yearly cross-sectional regressions. Both TASS and cluster-based style dummies are used. We begin in 1994 as TASS began keeping defunct funds in their data set that year. Panel B of Table VIII reports the results of this analysis.

Over the entire 12 year history, both specifications result in a negative $\omega$-score coefficient. The $\omega$-score is significant at the 5\% level using the Brown and Goetzmann (2003) style dummies and is significant at the $10 \%$ level using TASS style dummies. Hence, just as we find in our limited 1 year cross-sectional sample for 2006, operational risk is negatively related to fund returns. Of the 12 years, the operational risk variable is negatively related to returns in a majority of the years in both models. The one year in which the variable is positive and significant is 1998, which was an extremely difficult year for hedge funds due to the Russian debt crisis and the near collapse of LTCM. The1998 period is also a year of great attrition of hedge funds, which would eliminate expost some of the riskiest funds in the sample - a selection bias that is known to induce a spurious ex-post cross-sectional relationship between risk and returns (see Fung and Hsieh (2000, 2002), and Liang (2000)). 
In Panel $\mathrm{C}$ we consider the extent to which our operational risk $\omega$-score predicts leverage. Consistent with results reported in Table IV, the results clearly show that funds with high $\omega$-scores constructed from database variables observable at the time are correlated with differences in leverage. Further, these differences in leverage are not due to fund style differences, defined in various ways. ${ }^{47}$

These results suggest that while it may be difficult to construct a perfect proxy for Form ADV conflict variables going forward, in the absence of such filings it is possible to construct a univariate measure of operational risk based solely on observable characteristics reported in the TASS database.

\section{E. Investor Flows and Operational Risk}

In the analysis thus far, we find evidence that the operational risk variables in Form ADV filings by hedge fund managers are potentially relevant to expectations about returns. At the same time, we also find evidence that equity investors and lenders to problem funds are able to differentiate them from nonproblem funds. Problem funds are more likely to have less average and maximum leverage, and are more likely to have an owner with an ownership stake greater than $75 \%$. These results are consistent with the redundancy hypothesis, the conjecture that major debt and equity investors have access to information that allows them to distinguish between funds on the basis of their operation risk component even absent mandated Form ADVdisclosure. Our canonical correlation analysis shows one such separating mechanism that relies upon existing (albeit costly) hedge fund databases. In this section, we ask whether individual investors are able to differentiate between problem and nonproblem funds absent the Form ADV filing 
information. We have already found some evidence consistent with this ability. Problem funds have lower incentive fees, perhaps because they have to compensate for reputational issues. A more powerful test of the redundancy hypothesis, however, is to check whether investor flows respond equally to good performance by problem and nonproblem funds.

$<$ Insert Table IX about here $>$

Table IX reports the results of a flow-performance regression applied to the crosssection of all funds. ${ }^{48}$ Annual fund flow, defined as the percentage change in assets in a given year, net of asset returns and assuming end-of-year investment, is regressed on the rank for the fund within style, separated into three segments to allow for High, Middle, and Low performance. ${ }^{49}$ This separation is due to considerable previous evidence in the mutual fund sector that the flow-performance relationship is stronger for higher-ranked funds. Next we include the operational risk score constructed using the canonical correlation analysis, and a set of interaction terms taking the product of the operational risk score with the rank. Note that there is no apparent or significant difference between the flow-performance relationship and the operational risk score, nor is there a consistent pattern in the interaction terms. Operational risk factors do not appear to influence fund flow. The fact that investors do not take these factors into account was the motivation behind the SEC rule change that mandated disclosure of information material to a determination of operational risk. 


\section{Conclusion}

The hedge fund industry has enjoyed tremendous growth over the past several years. This growth led to an in-depth review of hedge fund activities by the SEC, and in 2004 resulted in the adoption of new rules and rule amendments that greatly expanded the number of hedge fund managers required to register with the SEC as investment advisers and file Form ADV. The SEC argued that Form ADV disclosure was necessary to provide material information to hedge fund investors concerned about operational risk. These rule changes were resisted by the hedge fund industry, which argued that the Form ADV filing requirement was unnecessarily burdensome given that the information disclosed could be obtained in other ways. Shortly after the first filing date in February 2006, the Federal Courts struck down this filing requirement.

By matching every Form ADV filed in February 2006 to the TASS hedge fund database, we are able to show that these disclosures do indeed contain information that can be used to measure operational risk. Legal, regulatory, and other problems are highly associated with measures of conflict of interest reported on those forms. However, is this information material to investors? To answer this question, we examine the hypothesis that the disclosures provided redundant information to equity investors, lenders, and share investors in hedge funds.

We test the redundancy hypothesis in several ways. We examine differences in ownership structure and find that problem funds had a higher likelihood of an owner with a stake greater than $75 \%$, and more indirect ownership. This is consistent with problem funds having less access to equity capital. We next examine differences in leverage. Controlling for the effects of style and the issues of retrospective definition of operational 
risk, we find strong evidence that problem funds and funds with higher operational risk tend to have lower average leverage. Since the ownership structures and degree of leverage pre-date Form ADV disclosure, we conclude that this disclosure is not material to well-informed capital market participants.

Finally, we test whether hedge fund investors are able to distinguish between problem and nonproblem funds. In contrast to the earlier findings, operational risk indicators have no influence on the well-documented flow-performance relationship. This suggests that Form ADV disclosures contain information not generally available to investors. While registration is not costless, an argument can be made that the information disclosed is indeed material to investors and that mandatory disclosure would level the informational playing field. However, mandatory disclosure in February 2006 did not help the investors at Amaranth Advisors LLC, the well-known hedge fund that collapsed in September 2006. ${ }^{50}$ This fund does not appear to have filed Form ADV in February. Given that Amaranth was not exempt from the filing requirement, failure to file should have been highly informative. We cannot exclude the possibility that the high net worth individuals and institutions continued to invest in Amaranth despite knowing all that there was to know about this company. In other words, disclosure might meet the stated purpose of providing information that allows investors to avoid operational risk. However, it might not be material information if investors, having access to this information, choose not to act upon it. 


\section{REFERENCES}

Agarwal, Vikas, and Narayan Y. Naik, 2000, Multi-period performance persistence analysis of hedge funds, Journal of Financial and Quantitative Analysis 35, 327-342.

Agarwal, Vikas, Naveen D. Daniel, and Narayan Y. Naik, 2006, Flows, performance, and managerial incentives in the hedge fund industry, Working paper, London Business School.

Altman, Edward I., 1968, Financial ratios, discriminate analysis and the prediction of corporate bankruptcy, Journal of Finance 23, 589-609.

Almeida, Heitor V., and Daniel Wolfenzen, 2006, A theory of pyramidal ownership and family business groups, Journal of Finance 61, 2637-2680.

Australian Prudential Regulatory Authority (APRA), 2004, Report into irregular currency options trading at the National Australia Bank 23 March 2004.

Baquero, Guillermo, and Marno Verbeek, 2006, A portrait of hedge fund investors: Flows, performance and smart money, Working paper, RSM Erasmus University.

Brown, Stephen J., and William N. Goetzmann, 1997, Mutual fund styles, Journal of Financial Economics 43, 373-399.

Brown, Stephen. J., and William. N. Goetzmann, 2003, Hedge funds with style, The Journal of Portfolio Management 29, 101-112.

Brown, Stephen J., William N. Goetzmann, Takato Hiraki, Noriyoshi Shiraishi, and Masahiro Watanabe, 2002, Investor sentiment in Japanese and U.S. daily mutual fund flows, Working paper, Yale School Management (http://ssrn.com/abstract=302829).

Brown, Stephen J., William. N. Goetzmann, Roger G. Ibbotson, and Stephen A. Ross, 1992, Survivorship bias in performance studies, Review of Financial Studies 5, 553-580.

Brown, Stephen J., William N. Goetzmann, and James Park, 2001, Careers and survival: Competition and risk in the hedge fund and CTA industry, Journal of Finance 56, 18691886.

Brunnermeier, Markus K., and Stefan Nagel, 2004, Hedge funds and the technology bubble, Journal of Finance 59, 2013-2040.

Cantale, Salvatore, 1996. The choice of a foreign market as a signal, Working paper, INSEAD. 
Chevalier, Judith A. and Glenn Ellison, 1999, Are some mutual fund managers better than others? Cross-sectional patterns in behavior and performance, The Journal of Finance 54, 875-899.

Cremers, Martijn, K. J., Joost Driessen, Pascal Maenhout, and David Weinbaum, 2006, Does skin in the game matter? director incentives and governance in the mutual fund industry, Working paper, Yale School of Management.

Demsetz, Harold, and Belen Villalonga, 2001, Ownership structure and corporate performance, Journal of Corporate Finance 7, 209-233.

Ding, Bill, and Russ Wermers, 2006, Mutual fund performance and governance structure: The Role of portfolio managers and boards of directors, Working paper, SUNY at Albany and University of Maryland.

Ding, Bill, Mila Getmansky, Bing Liang, and Russ Wermers, 2006, Market volatility, investor flows, and the structure of hedge fund markets, Working paper, University of Massachusetts.

Doidge, Craig, Andrew G. Karolyi, and Rene M. Stulz, 2004, Why are foreign firms listed in the U.S. worth more? Journal of Financial Economics 71, 205-238.

Dugar, Amitabh, and Siva Nathan, 1995, The effects of investment banking relationships on financial analysts' earnings forecasts and investment recommendations, Contemporary Accounting Research 12, 131-160.

Fama, Eugene F., and James D. MacBeth, 1973, Risk, return, and equilibrium: Empirical tests, Journal of Political Economy 81, 607-636.

Fontnouvelle, Patrick de, Virginia DeJesus-Rueff, John Jordan, and Eric Rosengren, 2003, Using loss data to quantify operational risk, Working paper, Federal Reserve Bank of Boston.

Fontnouvelle, Patrick de, Virginia DeJesus-Rueff, John Jordan, and Eric Rosengren, 2006, Capital and risk: new evidence on implications of large operational losses, Journal of Money, Credit and Banking 38, 1819-1846.

Fuerst, Oren, 1998, A theoretical analysis of the investor protection regulations argument for global listing of stocks, Working paper, Yale School of Management.

Fung, William, and David A. Hsieh, 2000, Performance characteristics of hedge funds and CTA funds: Natural versus spurious biases, Journal of Financial and Quantitative Analysis 35, 291-307.

Fung, William, and David A. Hsieh, 2002, Benchmarks of hedge fund performance: Information content and measurement biases, Financial Analysts Journal 58, 22-34. 
Getmansky, Mila, 2006, The life cycle of hedge funds: fund flows, size and Performance, Working paper, University of Massachusetts.

Getmansky, Mila, Andrew W. Lo, and Igor Makarov, 2004, An econometric model of serial correlation and illiquidity in hedge fund returns, Journal of Financial Economics 74, 529-609.

Goetzmann, William N., Jonathan E. Ingersoll, Matthew I. Spiegel, and Ivo Welch, 2004, Portfolio performance manipulation and manipulation-proof performance measures, Yale ICF Working Paper No. 02-08, Available at SSRN: http://ssrn.com/abstract=302815.

Gompers, Paul A., and Josh Lerner, 1999, Conflict of interest in the issuance of public securities: Evidence from venture capital, Journal of Law and Economics 42, 1-28.

Harvey, Campbell R., Karl V. Lins, and Andrew H. Roper, 2004, The effect of capital structure when expected agency costs are extreme, Journal of Financial Economics 74, 330 .

Heckman, James J., 1979, Sample selection bias as a specification error, Econometrica 47, 153-161.

Himmelberg, Charles, Robert G. Hubbard, and Darius Palia, 1999, Understanding the determinants of managerial ownership and the link between ownership and performance, Journal of Financial Economics 53, 353-384.

Holderness, Clifford G., Radall S. Kroszner, and Dennis P. Sheehan, 1999, Were the good old days that good? Evolution of managerial stock ownership and corporate governance since the great depression, Journal of Finance 54, 435-469.

Hotelling, Harold, 1936, Relations between two sets of variables, Biometrica 28, 321377.

Khorana, Ajay, and Henri Servaes, 2007, Conflicts of interest and competition in the mutual fund industry, Working paper, London Business School.

Lantsman, Yakov L., and Christopher M. Lewis, 2005, What is a fair price to transfer the risk of unauthorized trading? A case study on pricing operational risk, Working paper, The Hartford Financial Services Group and Fitch Risk Management, Inc.

Liang, Bing, 2000, Hedge funds: The living and the dead, Journal of Financial and Quantitative Analysis 35, 309-326.

Liang, Bing, 2003, The accuracy of hedge fund returns, Journal of Portfolio Management 29, 111-122.

Liang, Kung-Yee, and Scott L. Zeger, 1986, Longitudinal data analysis using generalized linear models, Biometrika 73, 13-22. 
Lin, Hsiou-wei, and Maureen McNichols, 1998, Underwriting relationships, analysts' earnings forecasts and investment recommendations, Journal of Accounting and Economics 25, 101-128.

McConnell, John J., and Henri Servaes, 1990, Additional evidence on equity ownership and corporate value, Journal of Financial Economics 27, 595-612.

Michaely, Roni, and Kent L. Womack, 1999, Conflicts of interest and the credibility of underwriter analyst recommendations, Review of Financial Studies 12, 653-686.

Moel, Alberto, 1999, The role of information disclosure on stock market listing decisions: The case of foreign firms listing in the U.S., Working paper, Harvard Business School.

Morck, Randall, Andrei Shleifer, and Robert W. Vishny, 1988, Management ownership and market valuation: An Empirical Analysis, Journal of Financial Economics 20, 293315.

Morgan, John, 2004, Dissolving a partnership (un)fairly, Economic Theory 23, 909-923.

Newey, Whitney K., and Kenneth D. West, 1987, A Simple positive semi-definite, heteroskedasticity and autocorrelation consistent covariance matrix, Econometrica 55, 703-708.

Press, James S., 1972, Applied Multivariate Analysis. (Holt, Rinehart and Winston, Inc., New York).

PriceWaterhouseCoopers (PwC), 2004, Investigation into foreign exchange losses at the National Australia Bank, 12 March 2004, Available at http://www.nabgroup.com/vgnmedia/downld/pwcreport.pdf.

Sirri, Erik R., and Peter Tufano, 1998, Costly search and mutual fund flows, The Journal of Finance 53, 1589-1622.

Sylla, Edith D., 2003, Business ethics, commercial mathematics, and the origins of mathematical probability, History of Political Economy 35, 309-337. 
Table I

Descriptive Statistics of TASS Data

This table presents descriptive statistics for funds whose management companies filed Form ADV and are reported on the TASS database as of 31 December 2005. The cross-section sample mean and median of these descriptive statistics are compared with those of the entire live TASS database as of the same date, together with the difference in sample means and a measure of the significance of the difference. Return is the average return over the life of the fund. Autocorrelation is the first order autocorrelation of the fund's returns. Mfee is the management fee, reported in percent. Ifee is the incentive fee, reported in percent. Min. Invt. is the minimum investment of the fund and Assets are the assets of the fund in millions of dollars Leverage, Margin and High Water Mark are one if the fund uses leverage, uses margin, or has a high water mark, respectively. Lockup Period is measured in months. Sub. Freq. is the subscription frequency measured in days and Red. Freq. is the redemption frequency also measured in days. **, * indicate significance at the $1 \%$ and $5 \%$ level, respectively.

\begin{tabular}{|c|c|c|c|c|c|c|c|c|c|c|}
\hline & \multicolumn{4}{|c|}{ Matched Funds } & \multicolumn{4}{|c|}{ All TASS Live Funds } & \multirow[b]{2}{*}{ Diff } & \multirow[b]{2}{*}{$p$-value } \\
\hline & $\mathrm{N}$ & Mean & Median & Std. Dev. & $\mathrm{N}$ & Mean & Median & Std. Dev. & & \\
\hline Return & 2282 & 0.96 & 0.83 & 0.79 & 3998 & 0.93 & 0.79 & 0.88 & 0.03 & 0.22 \\
\hline Std. Dev. & 2279 & 2.71 & 1.99 & 2.27 & 3992 & 2.78 & 2.06 & 2.38 & -0.07 & 0.11 \\
\hline Skewness & 2270 & 0.01 & -0.05 & 1.14 & 3975 & 0.01 & -0.06 & 1.11 & 0.00 & 0.87 \\
\hline Kurtosis & 2261 & 2.62 & 1.02 & 6.59 & 3958 & 2.57 & 0.97 & 6.21 & 0.05 & 0.81 \\
\hline Autocorrelation & 2240 & 0.14 & 0.14 & 0.20 & 3919 & 0.12 & 0.13 & 0.20 & 0.02 & $0.00^{* *}$ \\
\hline Sharpe ratio & 2279 & 0.39 & 0.30 & 0.72 & 3992 & 0.34 & 0.28 & 0.59 & 0.05 & $0.01^{*}$ \\
\hline Mfee & 2298 & 1.38 & 1.50 & 0.51 & 4019 & 1.44 & 1.50 & 0.58 & -0.06 & $0.00^{* *}$ \\
\hline Ifee & 2298 & 17.13 & 20.00 & 6.18 & 4019 & 16.27 & 20.00 & 6.87 & 0.86 & $0.00^{* *}$ \\
\hline Min. Invt. & 2295 & 1.23 & 0.50 & 8.01 & 4012 & 3.84 & 0.40 & 112.93 & -2.61 & 0.15 \\
\hline Assets & 1989 & 186.64 & 55.00 & 427.16 & 3503 & 181.11 & 48.00 & 439.36 & 5.53 & 0.65 \\
\hline Leverage & 2298 & 0.56 & 1.00 & 0.50 & 4019 & 0.56 & 1.00 & 0.50 & 0.00 & 0.51 \\
\hline Margin & 1733 & 0.46 & 0.00 & 0.50 & 2938 & 0.44 & 0.00 & 0.50 & 0.02 & 0.18 \\
\hline High water Mark & 2298 & 0.80 & 1.00 & 0.40 & 4019 & 0.76 & 1.00 & 0.43 & 0.04 & $0.00^{* *}$ \\
\hline Lockup Period & 2298 & 4.36 & 0.00 & 6.63 & 4019 & 3.55 & 0.00 & 7.00 & 0.81 & $0.00^{* *}$ \\
\hline Sub. Freq. & 2279 & 36.02 & 30.00 & 25.40 & 3972 & 34.43 & 30.00 & 25.22 & 1.59 & $0.01^{*}$ \\
\hline Red. Freq. & 2284 & 83.00 & 90.00 & 85.88 & 4001 & 69.21 & 30.00 & 75.76 & 13.79 & $0.00^{* *}$ \\
\hline
\end{tabular}




\section{Table II}

\section{Comparison of Problem and Nonproblem Funds}

This table reports cross-sectional means, medians and the difference in means of descriptive statistics for both Problem and Nonproblem funds in our population of hedge funds filing Form ADV. Problem funds are any TASS fund whose management company answered "Yes" to any of the questions on Item 11 of Form ADV. Nonproblem funds are all other TASS funds that filed Form ADV. Panel A reports results for performance statistics. Avg Return, Std Dev, $1^{\text {st }}$ Order AC, Sharpe ratio, and Appraisal Ratio are the average return of the fund, the standard deviation, the first-order autocorrelation, Sharpe ratio, and appraisal ratio of the fund over its life. Panel $\mathrm{B}$ reports results for external conflicts of interest, while Panel $\mathrm{C}$ breaks down internal conflict data. Broker/Dealer is one if the fund has a related broker/dealer. Investment Comp is one if the fund has a related investment company. Investment Adviser, Commodities Broker, Bank, Insurance and Sponsor of LLP are one if the fund is related to one of these respective companies. BuySellYourOwn is one if the company buys and sells between itself and clients. BuySellYourselfClients is one if a related party buys and sells securities also recommended to the fund. RecSecYouOwn is one if the fund recommends securities in which a related party has an ownership interest. AgencyCrossTrans is one if the fund performs agency cross-transactions. RecUnderwriter is one if a related party recommends securities to clients for which they are the underwriter. RecSalesInterest is one if a related party recommends securities with a sales interest. OtherResearch is one if the fund uses external research. Panel D looks at fund/manager characteristics and governance/ownership variables, respectively. High Water Mark, Leveraged, and Margin are one if the fund has a high water mark, uses leverage, or uses margin. Direct Owners represents the number of direct owners. Controlling is the number of controlling owners. $75 \%$ ownership is the percentage of owners who own at least $75 \%$ of the fund. Domestic Direct Corp gives the number of domestic corporations listed as direct owners. Indirect Owners represents the number of indirect owners. $* *, *$ indicate significance at the $1 \%$ and $5 \%$ level, respectively.

Panel A: Performance Statistics and Fund/Manager Characteristics

\begin{tabular}{|c|c|c|c|c|c|c|c|c|}
\hline & \multicolumn{3}{|c|}{ Problem Funds } & \multicolumn{3}{|c|}{ Nonproblem Funds } & \multirow[b]{2}{*}{ Diff } & \multirow[b]{2}{*}{$p$-value } \\
\hline & $\bar{N}$ & Mean & Median & $\mathrm{N}$ & Mean & Median & & \\
\hline Avg Return & 310 & 0.77 & 0.68 & 1603 & 0.91 & 0.79 & -0.14 & $0.00^{\star *}$ \\
\hline Std Dev & 308 & 2.50 & 1.66 & 1568 & 2.71 & 2.02 & -0.21 & 0.15 \\
\hline $1^{\text {st }}$ order AC & 283 & 0.12 & 0.14 & 1441 & 0.12 & 0.13 & 0.00 & 0.60 \\
\hline Sharpe ratio & 308 & 0.28 & 0.25 & 1568 & 0.36 & 0.26 & -0.08 & $0.01^{*}$ \\
\hline Appraisal Ratio & 303 & -0.02 & 0.03 & 1548 & 0.06 & 0.05 & -0.08 & $0.02^{* *}$ \\
\hline AUM (\$mm) & 334 & 217.32 & 59.18 & 1653 & 179.96 & 54.00 & 37.36 & 0.20 \\
\hline Age (Years) & 367 & 5.60 & 4.50 & 1929 & 4.96 & 3.83 & 0.64 & $0.01^{* *}$ \\
\hline Min Investment (\$mm) & 367 & 0.96 & 0.50 & 1926 & 1.28 & 0.50 & -0.32 & 0.33 \\
\hline Management Fee (\%) & 367 & 1.37 & 1.50 & 1929 & 1.38 & 1.50 & -0.01 & 0.71 \\
\hline Incentive Fee (\%) & 367 & 15.25 & 20.00 & 1929 & 17.49 & 20.00 & -2.24 & $0.00^{* *}$ \\
\hline High Water Mark & 367 & 0.69 & 1.00 & 1929 & 0.82 & 1.00 & -0.13 & $0.00^{* *}$ \\
\hline Lockup Period (months) & 367 & 4.00 & 0.00 & 1929 & 4.43 & 0.00 & -0.43 & 0.21 \\
\hline
\end{tabular}


Panel B: External Conflicting Relationships

\begin{tabular}{|c|c|c|c|c|c|c|}
\hline \multirow[b]{2}{*}{ With: } & \multicolumn{2}{|c|}{ Problem Funds } & \multicolumn{2}{|c|}{ Nonproblem Funds } & \multirow[b]{2}{*}{ Diff } & \multirow[b]{2}{*}{$p$-value } \\
\hline & $\mathrm{N}$ & $\%$ Yes & $\mathrm{N}$ & $\%$ Yes & & \\
\hline Broker/Dealer & 368 & 73.1 & 1929 & 23.7 & 49.4 & $0.00^{\star *}$ \\
\hline Investment Comp & 368 & 50.3 & 1929 & 15.8 & 34.5 & $0.00^{* *}$ \\
\hline Investment Adviser & 368 & 73.9 & 1929 & 41.6 & 32.3 & $0.00^{* *}$ \\
\hline Commodities Broker & 368 & 53.5 & 1929 & 20.7 & 32.8 & $0.00^{* *}$ \\
\hline Bank & 368 & 40.5 & 1929 & 9.8 & 30.7 & $0.00^{* *}$ \\
\hline Insurance & 368 & 39.9 & 1929 & 8.3 & 31.6 & $0.00^{* *}$ \\
\hline Sponsor of LLP & 368 & 56.8 & 1929 & 21.5 & 35.3 & $0.00^{* *}$ \\
\hline
\end{tabular}

Panel C: Internal Conflicts

\begin{tabular}{|c|c|c|c|c|c|c|}
\hline & \multicolumn{2}{|c|}{ Problem Funds } & \multicolumn{2}{|c|}{ Nonproblem Funds } & \multirow[b]{2}{*}{ Diff } & \multirow[b]{2}{*}{$p$-value } \\
\hline & $\mathrm{N}$ & $\%$ Yes & $\mathrm{N}$ & $\%$ Yes & & \\
\hline BuySellYourOwn & 368 & 30.7 & 1929 & 8.3 & 22.4 & $0.00^{* *}$ \\
\hline BuySellYourselfClients & 368 & 84.8 & 1929 & 69.3 & 15.5 & $0.00^{* *}$ \\
\hline RecSecYouOwn & 368 & 75.5 & 1929 & 50.4 & 25.1 & $0.00^{* *}$ \\
\hline AgencyCrossTrans & 368 & 30.7 & 1929 & 2.3 & 28.4 & $0.00^{\star *}$ \\
\hline RecUnderwriter & 368 & 69.0 & 1929 & 47.0 & 22.0 & $0.00^{* *}$ \\
\hline RecSalesInterest & 368 & 22.6 & 1929 & 15.7 & 6.9 & $0.00^{* *}$ \\
\hline RecBrokers & 368 & 46.7 & 1929 & 38.0 & 8.7 & $0.00^{* *}$ \\
\hline OtherResearch & 368 & 81.0 & 1929 & 70.5 & 10.5 & $0.00^{* *}$ \\
\hline
\end{tabular}

Panel D: Ownership/Capital Structure

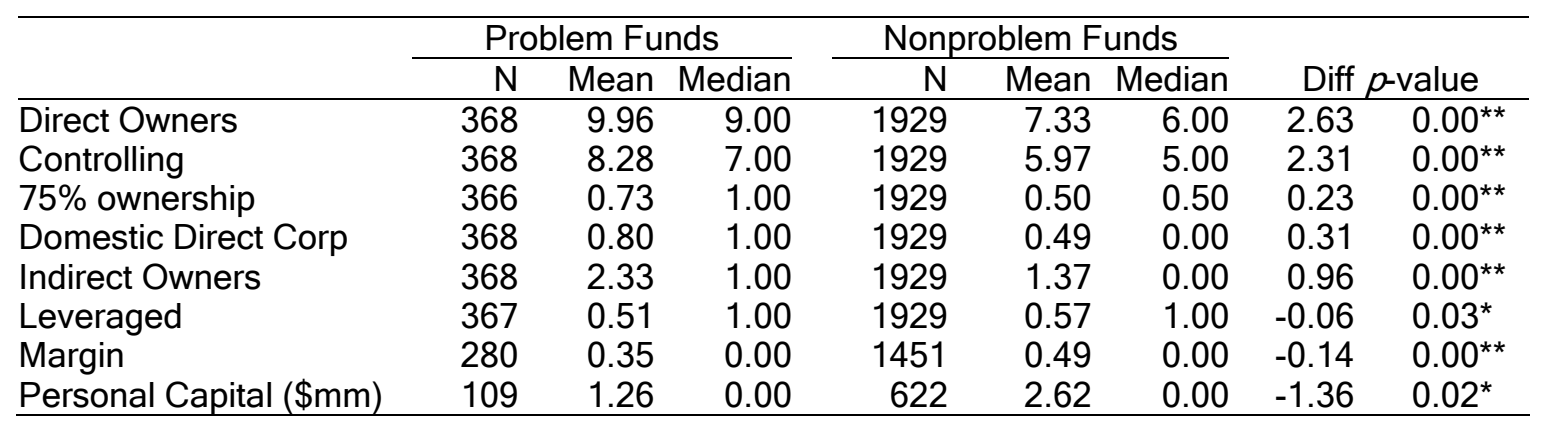




\section{Table III}

\section{Probit Model Analysis on the "Problem" Variable}

Probit results are reported in this table. The dependent variable in all models is one if the fund has a problem, and zero if the fund does not have a problem. The model is modeled such that the results aim to fit the "problem" set of data (i.e., 1). $\log$ (Assets) is the log of the assets under management in dollars. High Water Mark is one if the fund has a high water mark. Mean Return is the average return over the life of the fund. Incentive Fee is the fund's incentive fee in percent. Relationship is one if the fund has any external conflict of interest listed in Table II. AgencyCrossTrans is one if the fund performs agency cross transactions. RecSecYouOwn is one if the fund recommends securities in which a related party has an ownership interest. BuySellYourOwn is one if the company buys and sells between itself and clients. OtherResearch is one if the fund uses external research. $75 \%$ ownership is the percentage of direct owners who own at least $75 \%$ of the company. Direct Domestic is the number of domestic corporations listed as direct owners. Unreported style dummies are included to control for style differences. ${ }^{* *}$, * indicate significance at the $1 \%$ and $5 \%$ level, respectively.

\begin{tabular}{|c|c|c|c|c|c|c|}
\hline & \multicolumn{2}{|c|}{ Model 1} & \multicolumn{2}{|c|}{ Model 2} & \multicolumn{2}{|c|}{ Model 3} \\
\hline & coefficient & Chi-Sq & coefficient & Chi-Sq & coefficient & Chi-Sq \\
\hline$\overline{\text { Log(Assets) }}$ & 0.014 & 0.49 & -0.022 & 1.08 & -0.007 & 0.00 \\
\hline High Water Mark & -0.199 & $5.36^{*}$ & -0.114 & 1.49 & -0.149 & 2.31 \\
\hline Mean Return & & & & & 0.059 & 1.23 \\
\hline Incentive Fee & -0.037 & $21.44^{* *}$ & -0.038 & $20.29^{\star *}$ & -0.036 & $16.82^{* *}$ \\
\hline Relationship & & & 0.759 & $66.17^{* *}$ & 0.652 & $44.44^{* *}$ \\
\hline AgencyCrossTrans & & & & & 1.400 & $121.65^{\star *}$ \\
\hline RecSecYouOwn & & & 0.345 & $17.70^{* *}$ & 0.374 & $19.32^{* *}$ \\
\hline BuySellYourOwn & & & 0.695 & $49.38^{* *}$ & & \\
\hline OtherResearch & & & 0.294 & $8.43^{* *}$ & 0.226 & $4.53^{*}$ \\
\hline 75\% ownership & & & & & 0.551 & $38.15^{\star *}$ \\
\hline Direct Domestic & & & & & 0.134 & $9.60^{* *}$ \\
\hline Pseudo $\mathrm{R}^{2}$ & $3.89 \%$ & & $16.59 \%$ & & $25.30 \%$ & \\
\hline Num. Obs. & 1,986 & & 1,986 & & 1,969 & \\
\hline
\end{tabular}




\section{Table IV \\ Problems and Leverage}

This table reports the results of several tests of the relationship between fund leverage and measures of operational risk. This table reports tests for mean differences in three leverage measures between problem and nonproblem funds. The three measures are Leveraged, which is a zero-one variable reported by TASS, Avg. Leverage, the average fund leverage reported by TASS, Maximum Leverage the maximum leverage of the fund reported by TASS. The test is applied to all funds in the match sample, then to a subset that excludes funds-of-funds, and finally to a set for which the top $5 \%$ in terms of leverage are winsorized. $* *, *$ indicate significance at the $1 \%$ and $5 \%$ level, respectively.

\begin{tabular}{|c|c|c|c|c|c|c|}
\hline & \multicolumn{2}{|c|}{ Problem Funds } & \multicolumn{2}{|c|}{ Nonproblem Funds } & \multirow[b]{2}{*}{ Diff } & \multirow[b]{2}{*}{$p$-value } \\
\hline & $\mathrm{N}$ & Mean & $\mathrm{N}$ & Mean & & \\
\hline \multicolumn{7}{|c|}{ All Funds in Matched Sample } \\
\hline Leveraged & 367 & 0.51 & 1,929 & 0.57 & -0.06 & $0.03^{\star \star}$ \\
\hline Avg.Leverage & 280 & 52.20 & 1,451 & 85.31 & -33.11 & $0.00^{* *}$ \\
\hline Maximum Leverage & 280 & 96.82 & 1,451 & 140.68 & -43.86 & $0.00^{* *}$ \\
\hline \multicolumn{7}{|c|}{ Only Hedge Funds } \\
\hline Leveraged & 271 & 0.61 & 1,535 & 0.61 & 0.00 & 0.87 \\
\hline Avg. Leverage & 225 & 63.73 & 1,201 & 95.57 & -31.84 & $0.01^{* *}$ \\
\hline Maximum Leverage & 225 & 118.27 & 1,201 & 158.80 & -40.53 & $0.04^{*}$ \\
\hline \multicolumn{7}{|c|}{ All Funds in Matched Sample - Winsorized Top 5\% } \\
\hline Avg. Leverage & 280 & 43.34 & 1,451 & 65.15 & -21.81 & $0.00^{\star \star}$ \\
\hline Maximum Leverage & 280 & 81.46 & 1,451 & 108.33 & -26.87 & $0.00^{* *}$ \\
\hline
\end{tabular}




\section{Table V}

\section{Fund Distribution and Leverage by Style}

This table reports the breakdown of matches and leverage by style. The first two columns report the percentage of funds in each style for both the entire matched ADV sample and the problem group. The third column reports the average leverage for problem funds in each style while the last column reports the average leverage for nonproblem funds in each style.

\begin{tabular}{lrrrr}
\hline Category & Matched & Problem & Problem Avg. & Nonproblem Avg. \\
\hline Convertible Arbitrage & $4.22 \%$ & $7.07 \%$ & 118.04 & 170.24 \\
Dedicated Short & $0.70 \%$ & $0.00 \%$ & $\mathrm{n} / \mathrm{a}$ & 72.22 \\
Emerging Markets & $4.22 \%$ & $2.99 \%$ & 0.00 & 18.60 \\
Equity Neutral & $6.26 \%$ & $5.71 \%$ & 185.31 & 61.18 \\
Event Driven & $11.92 \%$ & $13.59 \%$ & 51.30 & 51.37 \\
Fixed Inc. Arbitrage & $6.05 \%$ & $3.26 \%$ & 287.50 & 415.89 \\
Fund of Funds & $21.31 \%$ & $26.09 \%$ & 6.47 & 36.04 \\
Global Macro & $3.57 \%$ & $0.81 \%$ & 140.00 & 134.24 \\
Long-Short Equity & $34.71 \%$ & $32.61 \%$ & 23.85 & 44.91 \\
Managed Futures & $3.48 \%$ & $4.08 \%$ & 19.34 & 91.01 \\
Multi-Strategy & $3.52 \%$ & $3.53 \%$ & 40.00 & 120.70 \\
\hline
\end{tabular}




\section{Table VI \\ Conflicts, Ownership, and Fund Returns}

This table reports results estimating the equation

$$
\begin{aligned}
& \text { AppraisalRatio }_{i}=\beta_{0}+\beta_{1} \text { LogAsset }_{i}+\beta_{2} \text { StdDev }_{i}+\beta_{3} \text { Onshore }_{i}+\beta_{4} \text { LockupPeriod }_{i} \\
& +\beta_{5} \text { IncentiveFee }_{i}+\beta_{6} \text { HighWaterMark }_{i}+\beta_{7} \text { Relationship }_{i}+\beta_{8} \text { DirectDomestic }_{i} \\
& +\beta_{9} 75 \% \text { Ownership }_{i}+\sum_{j=1}^{10} \gamma_{j} \text { StyleDummies }_{j i}+\varepsilon_{i}
\end{aligned}
$$

using the clustering Generalized Estimating Equations (GEE) approach of Liang and Zeger (1986) to account for correlations of the residual $\varepsilon_{i}$ of funds within the same fund management company. Appraisal ratios are calculated with monthly fund returns with respect to funds' respective style indices and U.S. Treasury Bill returns. LogAssets is the $\log$ of the assets under management in dollars. Std Dev is the standard deviation of a fund's returns over the life of the fund. Onshore is one if the fund is based in the United States. Incentive fee is the fund's incentive fee in percent. High Water Mark is one if the fund has a high water mark. Relationship is one if the fund has any external conflicts of interest. Direct Domestic is the number of domestic corporations listed as direct owners. $75 \%$ ownership is the percentage of direct owners who own at least $75 \%$ of the company. Unreported style dummies were included to control for style differences. Results are reported with the first 18 months of returns removed to control for backfill bias and clustered standard errors to control for non-independent management company returns.

\begin{tabular}{|c|c|c|c|c|c|c|}
\hline & \multicolumn{2}{|c|}{ Model 1} & \multicolumn{2}{|c|}{ Model 2} & \multicolumn{2}{|c|}{ Model 3} \\
\hline & coefficient & $t$-value & coefficient & $t$-value & coefficient & $t$-value \\
\hline Log(Assets) & 0.061 & $6.12^{* *}$ & 0.061 & $6.03^{* *}$ & 0.060 & $6.02^{* *}$ \\
\hline Std Dev & -0.027 & $-3.84^{* *}$ & -0.029 & $-4.18^{* *}$ & -0.029 & $-4.18^{* *}$ \\
\hline Onshore & 0.086 & $3.19^{* *}$ & 0.089 & $2.90^{* *}$ & 0.091 & $3.41^{* *}$ \\
\hline Lockup Period & & & 0.002 & 0.74 & & \\
\hline Incentive Fee & & & 0.008 & $3.23^{* *}$ & 0.008 & $3.12^{* *}$ \\
\hline High Water Mark & & & -0.109 & $-3.38^{* *}$ & -0.103 & $-3.17^{* *}$ \\
\hline Relationship & & & -0.008 & -0.23 & -0.001 & -0.02 \\
\hline Direct Domestic & & & & & -0.027 & -1.27 \\
\hline 75\% ownership & & & & & -0.078 & $-2.47^{*}$ \\
\hline Pseudo $\mathrm{R}^{2}$ & $5.57 \%$ & & $6.16 \%$ & & $6.51 \%$ & \\
\hline $\begin{array}{l}\text { Number of } \\
\text { observations }\end{array}$ & 1,642 & & 1,642 & & 1,642 & \\
\hline
\end{tabular}
The top and bottom $1 \%$ of appraisal ratios are winsorized to control for outliers. **,* indicate significance at the $1 \%$ and $5 \%$ level, respectively. 


\section{Table VII}

\section{Conflicts, Ownership, and Returns: Problem vs. Nonproblem Funds}

This table reports GEE estimation results using fund appraisal ratios as the dependent variable, and alternatively, returns on problem funds in excess of returns on a sample of nonproblem funds matched by style, size, age and return standard deviation. Appraisal ratios are calculated with monthly fund returns with respect to funds' respective style indices and U.S. Treasury Bill returns. Log (Assets) is the log of the assets under management in dollars. Std Dev is the standard deviation of a fund's returns over the life of the fund. Onshore is one if the fund is based in the United States. Incentive fee is the fund's incentive fee in percent. High Water Mark is one if the fund has a high water mark. Relationship is one if the fund has any external conflicts of interest. Direct Domestic is the number of domestic corporations listed as direct owners. 75\% ownership is the percentage of direct owners who own at least $75 \%$ of the company. Unreported style dummies were included to control for style differences. Results are reported with the first 18 months of returns removed to control for backfill bias and clustered standard errors to control for non-independent management company returns. The top and bottom $1 \%$ of appraisal ratios are winsorized to control for outliers. $* *, *$ indicate significance at the $1 \%$ and $5 \%$ level, respectively.

\begin{tabular}{|c|c|c|c|c|c|c|c|c|c|}
\hline & \multicolumn{3}{|c|}{$\begin{array}{l}\text { Problem Fund } \\
\text { Appraisal Ratios }\end{array}$} & \multicolumn{2}{|c|}{$\begin{array}{l}\text { Nonproblem Fund } \\
\text { Appraisal Ratios }\end{array}$} & & \multicolumn{2}{|c|}{$\begin{array}{c}\text { Problem Fund } \\
\text { Matched Sample Returns }\end{array}$} & \\
\hline & coefficient & $t$-value & & coefficient & $t$-value & & coefficient & $t$-value & \\
\hline Log(Assets) & 0.073 & 4.17 & ** & 0.047 & 4.19 & $* *$ & 0.011 & 0.33 & \\
\hline Fund Age (Years) & 0.009 & 1.31 & & 0.016 & 3.57 & $* *$ & -0.014 & -0.93 & \\
\hline Std Dev & -0.018 & -1.21 & & -0.040 & -4.73 & $* *$ & 0.010 & 0.31 & \\
\hline Onshore & 0.120 & 1.80 & & 0.061 & 2.14 & * & 0.151 & 1.74 & \\
\hline Incentive Fee & 0.003 & 0.44 & & 0.009 & 3.38 & $* *$ & -0.023 & -2.09 & * \\
\hline High Water Mark & -0.018 & -0.25 & & -0.056 & -1.56 & & -0.123 & -1.31 & \\
\hline Relationship & -0.251 & -2.53 & * & 0.023 & 0.58 & & -0.426 & -2.18 & * \\
\hline Direct Domestic & 0.026 & 0.52 & & -0.027 & -1.18 & & -0.049 & -0.70 & \\
\hline Percent own $75 \%$ & -0.081 & -1.56 & & -0.075 & -2.15 & * & -0.264 & -2.37 & * \\
\hline $\mathrm{R}^{2}$ & $18.02 \%$ & & & $6.76 \%$ & & & $7.08 \%$ & & \\
\hline Num Obs. & 273 & & & 1,369 & & & 279 & & \\
\hline
\end{tabular}




\section{Table VIII}

\section{Canonical and Time Series Analysis of TASS and ADV Data}

This table reports the results of a canonical analysis relating operational risk ADV data to the observable TASS data. Panel A reports the results of the canonical analysis using 2,279 matched funds used to construct a univariate measure of operational risk, or $\omega$-score, using the linear combination implied by the TASS canonical variate. In Panel B we report regression results regressing annual fund return from 1994 to 2005 on the $\omega$-score updated each year using information in that year's TASS database on the basis of nine successive annual TASS data sets. Previous Returns are the average monthly returns from the previous year and Previous Std. Dev. is the monthly standard deviation from the previous year. Age and Size are the values from the end of the previous period. Other characteristic data are from the same period as the analysis. Reports Assets is a binary variable with a value of one if the fund reports assets and zero if it does not. Unreported style dummies and market betas were included in Panel B. The average number of observations is the average number of funds included in each year's cross section regression of fund returns against operational risk characteristic and style. Panel $\mathrm{C}$ shows the extent to which this measure of operational risk predicts leverage. The dependent variable in each regression is the average leverage of each fund as reported by TASS. The independent variable is that year's operational risk $\omega$-score. Unreported style dummies, as defined by TASS, and style dummies using the Brown-Goetzmann style classification procedure are included to control for style differences. ${ }^{* *},{ }^{*}$ indicate significance at the $1 \%$ and $5 \%$ level, respectively.

\begin{tabular}{lclc}
\hline \multicolumn{4}{c}{ Panel A: Canonical Correlation Results } \\
\hline TASS Variables & & ADV Variables \\
\hline Previous Returns & $-0.27^{* *}$ & AgencyCrossTrans & $0.06^{*}$ \\
Previous Std. Dev. & $-0.35^{* *}$ & RelBrokerDealer & $0.28^{* *}$ \\
Fund Age & $-0.07^{* *}$ & RellnvestComp & $0.24^{* *}$ \\
Log of Assets & $0.13^{* *}$ & RellnvAdviser & $0.24^{* *}$ \\
Reports Assets & $0.12^{* *}$ & RelCommod & $0.44^{* *}$ \\
Incentive Fee & $-0.88^{* *}$ & RelBank & $0.38^{* *}$ \\
Margin & $-0.29^{* *}$ & Rellnsur & $0.44^{* *}$ \\
Audited & $-0.19^{* *}$ & RelPartSponser & $0.30^{* *}$ \\
Personal Capital & $-0.29^{* *}$ & BuySellYourOwn & $0.08^{*}$ \\
Onshore & $-0.05^{* *}$ & BuySellYourselfClient & $-0.08^{* *}$ \\
Open to Inv. & 0.08 & RecSecYouOwn & $0.33^{* *}$ \\
Accepts Managed Accts & $-0.13^{* *}$ & RecUnderwriter & $0.26^{* *}$ \\
& & RecSalesInterest & $0.28^{* *}$ \\
& & RecBrokers & $-0.33^{* *}$ \\
Correlation Between & & OtherResearch & $-0.70^{* *}$ \\
TASS and ADV Panels & $0.42^{* *}$ & 75\% Ownership & $0.15^{* *}$ \\
\hline
\end{tabular}


Table VIII-Continued

\begin{tabular}{|c|c|c|c|c|}
\hline \multicolumn{5}{|c|}{ Panel B: Operational Risk Measure Predicting Returns } \\
\hline \multirow[b]{2}{*}{ Year } & \multicolumn{2}{|c|}{ TASS Style Dummies } & \multicolumn{2}{|c|}{ B-G Style Dummies } \\
\hline & coefficient & $t$-value & coefficient & $t$-value \\
\hline 1994 & $-3.72 \%$ & $-3.36^{* *}$ & $-2.28 \%$ & $-2.20^{*}$ \\
\hline 1995 & $0.20 \%$ & 0.21 & $0.10 \%$ & 0.12 \\
\hline 1996 & $-1.97 \%$ & $-2.38^{*}$ & $-3.27 \%$ & $-4.76^{\star *}$ \\
\hline 1997 & $-2.96 \%$ & $-3.49^{* *}$ & $-2.61 \%$ & $-3.71^{* *}$ \\
\hline 1998 & $2.84 \%$ & $3.23^{* *}$ & $0.42 \%$ & 0.60 \\
\hline 1999 & $-1.99 \%$ & -1.64 & $-0.13 \%$ & -0.14 \\
\hline 2000 & $0.19 \%$ & 0.21 & $-0.18 \%$ & -0.25 \\
\hline 2001 & $-0.96 \%$ & -1.57 & $-0.42 \%$ & -0.95 \\
\hline 2002 & $-2.61 \%$ & $-5.88^{* *}$ & $-1.48 \%$ & $-4.43^{* *}$ \\
\hline 2003 & $0.25 \%$ & 0.48 & $-0.41 \%$ & -1.12 \\
\hline 2004 & $-1.08 \%$ & $-2.88^{* *}$ & $-0.67 \%$ & $-2.45^{\star}$ \\
\hline 2005 & $0.06 \%$ & 0.14 & $-0.11 \%$ & -1.31 \\
\hline Average Value & $-0.98 \%$ & -1.87 & $-0.92 \%$ & $-2.66^{*}$ \\
\hline Average Adjusted- $R^{2}$ & $21.95 \%$ & & $40.17 \%$ & \\
\hline Average Number of Observations & 1,027 & & 1,027 & \\
\hline \multicolumn{5}{|c|}{ Panel C: Operational Risk Measure Predicting Leverage } \\
\hline & \multicolumn{2}{|c|}{ TASS Style Dummies } & \multicolumn{2}{|c|}{ B-G Style Dummies } \\
\hline Year & coefficient & $t$-value & coefficient & $\overline{t \text {-value }}$ \\
\hline 2001 & -22.87 & $-4.17^{* *}$ & -28.07 & $-5.48^{* *}$ \\
\hline 2002 & -18.45 & $-3.50^{* *}$ & -27.52 & $-5.81^{* *}$ \\
\hline 2003 & -25.33 & $-4.90^{* *}$ & -33.52 & $-7.23^{* *}$ \\
\hline 2004 & -29.12 & $-5.92^{* *}$ & -35.08 & $-8.26^{* *}$ \\
\hline 2005 & -18.48 & $-4.17 * *$ & -6.42 & $-6.83^{* *}$ \\
\hline Average Value & -22.85 & $-11.15^{* *}$ & -26.12 & $-5.08^{* *}$ \\
\hline Average Adjusted- $R^{2}$ & $13.79 \%$ & & $2.66 \%$ & \\
\hline Average Number of Observations & 2,279 & & 2,279 & \\
\hline
\end{tabular}




\section{Table IX}

\section{Operational Risk and Flow Analysis}

Table IX reports results estimating the fund flow equation

Flow $_{i t}=\beta_{0}+\beta_{1}$ LowRank $_{i t}+\beta_{2}$ MidRank $_{i t}+\beta_{3}$ HighRank $_{i t}+\beta_{4}$ Std Dev $_{i t}$

$+\beta_{5}$ CategoryFlow $_{i t}+\beta_{6}$ LogAssets $_{i t}+\beta_{7}$ ManagementFee $_{i t}+\beta_{8} \omega-$ score $_{i t}$

$+\beta_{9}$ LowRank $_{i t} \times \omega-$ score $_{i t}+\beta_{10}$ MidRank $_{i t} \times \omega-$ score $_{i t}+\beta_{11}$ HighRank $_{i t} \times \omega-$ score $_{i t}+\varepsilon_{i t}$

cross-sectionally using data for each year from 1994 to2005. Flows are computed annually using the following formula:

$$
\text { Flow }_{i t}=\frac{\left(\text { Assets }_{i t}-\text { Assets }_{i t-1} \times \operatorname{Return}_{i t}\right)}{\text { Assets }_{i t-1}} .
$$

Assets and returns are computed in the fund's native currency to avoid exchange rate affects. Low Rank, Mid Rank, and High Rank are computed as $\operatorname{Min}\left(\operatorname{Rank}_{\mathrm{t}-1}, 0\right)$, Min(Rank t-1 $_{\text {- Low Rank, 0), and Min(Rank }}$ - Mid Rank - Low Rank, 0), respectively, where Rank $_{\mathrm{t}-1}$ is the percentile level of the previous year's performance in the fund's TASS style. Std Dev is the previous year's monthly standard deviation. CategoryFlow is the average flow to that fund's particular style in year $t$. LogAssets is the log of the previous end of period's assets and ManagementFee is the current management fee level. The operational risk $\omega$-score measure is computed each year as in Table VIII. Model 1 includes the operational risk $\omega$-score only, whereas Model 2 also includes three interaction terms. Both models are run using the Fama and MacBeth (1973) framework. Standard errors are computed using Newey-West (1987) with one lag. ${ }^{* *}, *$ indicate significance at the $1 \%$ and $5 \%$ level, respectively.

\begin{tabular}{lrrrrr}
\hline & \multicolumn{2}{c}{ Model 1 } & & \multicolumn{2}{c}{ Model 2} \\
\cline { 2 - 3 } \cline { 5 - 6 } & coefficient & $t$-value & & coefficient & $t$-value \\
\hline LowRank & 0.596 & $6.10^{* *}$ & & 0.634 & $7.30^{* *}$ \\
MidRank & 0.977 & $6.89^{* *}$ & & 0.981 & $6.79^{* *}$ \\
HighRank & 0.905 & $11.69^{* *}$ & & 0.886 & $7.39^{* *}$ \\
Std Dev of monthly returns & -0.022 & $-5.44^{* *}$ & & -0.023 & $-5.79^{* *}$ \\
CategoryFlows & 0.685 & $9.80^{* *}$ & & 0.686 & $9.63^{* *}$ \\
LogAssets & -0.117 & $-6.45^{* *}$ & & -0.118 & $-6.52^{* *}$ \\
ManagementFees & -0.045 & $-3.06^{*}$ & & -0.044 & $-2.89^{*}$ \\
Operational Risk $\omega$-score & -0.010 & -1.61 & & 0.025 & 1.02 \\
Low Rank/ $\omega$-score interaction & & & & -0.019 & -0.15 \\
Mid Rank/ $\omega$-score interaction & & & & -0.202 & -1.78 \\
High Rank/ $\omega$-score interaction & & & & 0.085 & 0.62 \\
Adjusted-R & & & & & \\
Number of Observations & $14.00 \%$ & & & & \\
\hline
\end{tabular}




\section{Footnotes}

${ }^{1}$ According to Lipper TASS Inc., hedge fund assets under management have doubled over the last five years to over \$1 trillion in December 2005.

2 These quotations and further discussion can be found in the SEC proposed rules http://www.sec.gov/rules/final/ia-2333.htm.

${ }^{3}$ This model has been developed to explain the premium awarded to foreign firms that choose to register in the United States and submit themselves to stringent SEC disclosure requirements (see Cantale (1996), Doidge, Karolyi and Stulz(2004), Fuerst(1998) and Moel(1999)).

${ }^{4}$ Interestingly enough, we could not find a filing in February for Amaranth Advisors LLC, which failed in September. We believe they claimed exemption because they had fewer than 15 investors. This might be a case in which failure to file would have been highly informative to the investors in funds managed by Amaranth.

${ }^{5}$ The 2 year lockup period provision is included for the purpose of excluding venture capital and private equity firm managers from the filing requirement; however, hedge fund managers have been lengthening their lockups to two years to avoid the filing requirement.

See http://www.businessweek.com/magazine/content/04_52/b3914039_mz011.htm.

${ }^{6}$ http://www.sec.gov/rules/final/ia-2333.htm.

7 These limited hedge fund filings have already been used by academic researchers; Brunnermeier and Nagel (2004) use these filings to analyze the actions of hedge funds during the technology bubble. 
${ }^{8}$ According the Phil Goldstein, the hedge fund manager who successfully challenged the requirement in court, Form ADV "asked for everything from 'your last small-pox vaccination to every dirty joke you got on E-mail"' (Wall Street Journal June 28, 2006). Though this may be something of an exaggeration, the SEC estimated in advance of the rule changes that registration would cost around $\$ 45,000$, and this does not account for the requirement to hire compliance officers, who command between $\$ 200,000$ and $\$ 750,000$ (Wall Street Journal June 8, 2005), or the costs associated with purchasing software to better monitor trading, establishing policies governing their practices, and filing the required forms with the SEC. This cost would disproportionately affect smaller funds.

${ }^{9}$ INTERNATIONAL ASSOCIATION OF FINANCIAL ENGINEERS, Report of the Operational Risk Committee: Evaluating Operational Risk Controls, CONCLUSIONS AND FINDINGS ON THE TOPIC OF: "How should firms determine the effectiveness of their operational risk controls?" November 2001, www.iafe.org.

${ }^{10}$ The management failures associated with the rogue trading losses at National Australia Bank are well documented (APRA(2004), PWC(2004). Allied Irish Bank experienced a loss of almost $\$ 700$ million due to trading losses by one trader. See http://en.wikipedia.org/wiki/AIB_Group. In January 2008 Société Générale lost approximately $€ 4.9$ billion closing out positions incurred by a rogue trader. See http://en.wikipedia.org/wiki/January 2008 Soci\%C3\%A9t\%C3\%A9 G\%C3\%A9n\%C3 \%A9rale trading loss incident. 
11 See, for example, http://capco.com/alternative investment.html. However, this observation needs to be qualified. A firm in financial distress due to unfortunate investment outcomes might be more likely to cut corners on compliance and experience an operational risk event. We thank Michael Triguboff for this observation.

${ }^{12}$ Despite being difficult to quantitatively assess, there is ample evidence that operational risk is considered important in the financial marketplace. Fontnouvelle $(2003,2006)$ find that operational losses for banks are large and significant. In fact, the authors find the capital charge for operational risk is often larger than the charge for market risk. Lantsman and Lewis (2005) study the use of unauthorized trading insurance. They find banks and insurance companies value unauthorized trading differently, which has caused a slow adoption of this operational risk insurance product.

${ }^{13}$ See http://www.adviserinfo.sec.gov/IAPD/Content/IapdMain/iapd_SiteMap.aspx, the SEC investment advisor website.

${ }^{14}$ There are additional forms if the company has a "problem" as defined later in the paper or if the company also filed with a state agency.

${ }^{15}$ In some cases, the amount of information included on the DRP form was limited.

${ }^{16}$ Data are downloaded in March and April 2006. It is important to note the ADVs are dynamic in that the SEC will update the information on the investment advisor website as soon as new information is available. Thus, the data downloaded subsequent to April 2006 will not match exactly the data used in this study.

${ }^{17}$ A few of the funds also listed an investment advisor with a different name than the management company. We also include these companies in our search if the management company was not located. 
${ }^{18}$ We do not explicitly keep track of this breakdown, but estimate that fewer than $15 \%$ of all matches are made using the fund name.

${ }^{19}$ Some of the ADV filings do not list any funds. In these cases, the name and address of the ADV are used to verify a match.

${ }^{20}$ As of the beginning of April 2006, we are unable to match around 100 management companies in TASS with U.S. addresses and over \$25 million in assets. There are a variety of reasons for these companies not to be registered, including a lockup period change, a reduction in assets, or an error in the TASS database.

${ }^{21}$ See, for example, Getmansky, Lo, and Makarov (2004). Three liquidity measureslockup period, subscription frequency period, and redemption frequency period-are all significantly longer for the matched funds, which may be due to more of the matched funds being onshore, as onshore funds have more share restrictions.

${ }^{22}$ These results are also run excluding fund-of-funds as their structure is different than hedge funds. There are no material differences between these results and the reported results.

${ }^{23}$ These data were compiled by the company on March 17, 2006.

${ }^{24}$ Liang (2003) indicates that small funds are more likely to suffer auditing problems. The sample here does not include funds with less than \$25 million in assets. Hence, $14.3 \%$ could be an underestimate for hedge funds. Another caveat to this conclusion is that management companies with associated mutual funds might have a longer history of regularity scrutiny, which might lead to a higher incidence of violations and lawsuits. To examine that hypothesis we remove all funds with managers that have associated mutual fund companies and recalculate Table II. The results are unchanged. 
${ }^{25}$ Appraisal ratios are calculated by first regressing fund $i$ 's excess return on the fund's TASS style index $I$ excess return, $r_{i t}-R_{f t}=\alpha_{i}+\beta_{i}\left(r_{I t}-R_{f t}\right)+\varepsilon_{i t}, \quad i \in I$ where $R_{f t}$ is the coincident U.S. Treasury Bill return. The appraisal ratio is then given as the estimate of $\alpha_{i}$ in that regression divided by the residual standard deviation. We remove the first 18 months of returns to control for backfill bias and the top and bottom $1 \%$ of appraisal ratios are winsorized to control for outliers. We obtain similar results using S\&P500 index returns in place of TASS style index returns.

${ }^{26}$ Both the Sharpe ratio and alpha measures are misspecified and subject to manipulation given the non-linear payoffs commonly associated with hedge fund investment strategies (Goetzmann, Ingersoll, Spiegel, and Welch (2004)). Brown, Goetzmann, Ibbotson, and Ross (1992) argue that the appraisal ratio provides a measure of performance reasonably robust to the lookback bias frequently encountered when ranking managers by performance, and Agarwal and Naik (2000) further argue that this measure is particularly relevant for hedge funds given that it accounts for differences in leverage across funds.

${ }^{27}$ There is a high correlation between all of the conflict of interest variables.

${ }^{28}$ These and later terms refer to checkboxes on Form ADV. For complete definitions of these terms and explanations see the SEC website http://www.sec.gov/about/forms/formadv.pdf .

${ }^{29}$ The definition of a controlling owner is set by the SEC. This is not a flag set by the company itself.

${ }^{30}$ See, for example, Morgan (2004), who argues that individuals anticipating an unfair distribution mechanism in the case that the partnership dissolves may be reluctant to enter 
into the partnership in the first place. This would imply concentration of management when agency costs are extreme. This is an issue particularly in emerging economies. See Almeida and Wolfenzon (2006) and Harvey, Lins, and Roper (2004).

${ }^{31}$ One potential selection bias in the sample of Form ADV filers is that managers might have been sued simply because their funds had low returns. To examine this possibility, we tested whether the returns to firms in the fourth category (i.e., civil lawsuits) have significantly lower returns than the overall group of problem funds. They do not.

${ }^{32}$ See, for example, Morgan (2004). The problem of the fair division of an ongoing concern is one of the oldest problems in finance. Sylla (2003) quotes a translation of Huygens' "On Reckoning in Games and Luck." The quote is an apt one for hedge funds: "Since Gaming is becoming a Trade, I think it fit the Adventurers should be upon the Square."

${ }^{33}$ We perform a number of additional robustness checks. First, we considered whether more recent legal and regulatory problems are more relevant than older ones. We find this to be the case; the correlation between conflicts of interest and legal and regulatory problems is lower for funds with problems that occurred before 2002. We checked to see if extreme returns are driving results by Winsorizing the top and bottom $1 \%$ of returns. Results again are unaffected.

${ }^{34}$ These results are not driven by one category. Out of 10 style categories, problem funds have lower leverage in seven, approximately the same leverage in two, and higher leverage in only one. See Table V.

${ }^{35}$ This procedure, referred to as clustering Generalized Estimating Equations (GEE), is described in Liang and Zeger (1986). 
${ }^{36}$ Since we find that legal and regulatory problems are associated with leverage, we added average leverage to the regressions. The effect is insignificant and does not affect any results. We do not report these results in Tables VI and VII.

${ }^{37}$ To examine whether the reported results are an artifact of periods, styles, or length of return history, we also consider style mean adjusted returns and a variety of dummies controlling for both style and seasoning, as well as for individual year effects. The (unreported) results from this analysis are almost identical to the results reported in Tables VI and VII.

${ }^{38}$ Problem funds are matched by style, size, age, and risk. For every problem fund, we reduce the potential matches to only those nonproblem funds that are within the same style. To match in size, age and risk, we next calculate a distance between that fund and all the potential matching candidates in three dimensions. To ensure that size, age, and risk are treated equally in terms of the matching score, they are standardized by the standard deviation of fund values within that style. The nearest fund in this space is the closest match. We also match standardizing on the range of the characteristics and with matching portfolios. The results are similar to those reported.

${ }^{39}$ The slight change in observation count is due to the use of returns instead of appraisal ratios. Matching to the appraisal ratio sample has no affect on the results.

${ }^{40}$ For example, Morck, Shleifer, and Vishny (1988), Holderness, Krosner, and Sheehan (1999) and McConnell and Servaes (1990) find evidence of a non-linear relationship between percentage of insider ownership and Tobin's Q. Firm ownership structure is, of course, determined endogenously. Himmelberg, Hubbard, and Palia (1999) and Demsetz and Villalonga (2001) test for ownership effects on performance and find none, a result 
consistent with endogenous capital structure determination. The latter provides a useful summary of related studies.

${ }^{41}$ The problem versus nonproblem distinction is at the fund advisor level. Therefore, it is possible that not all of the funds for one particular management company are in the problem group. This should not systematically bias our results going forward. However, we also examine two subsets of our data to control for this issue. The first subset is management companies with five or fewer funds in TASS, and the second is management companies with three or fewer funds. The funds in these management companies would most likely have higher correlations in terms of personnel, and hence, it is more likely all funds would be problem funds. The results are consistent with those reported in the text, although the significance levels drop as a substantial portion of our sample is removed.

${ }^{42}$ This canonical correlation procedure was first proposed by Hotelling (1936). A good textbook treatment can be found in Press (1972). For another finance application, see Brown et al. (2002).

${ }^{43}$ Altman (1968) creates a related z-score model to study credit scoring.

${ }^{44}$ The magnitudes of these correlations are moderate, however.

${ }^{45}$ Instead of assuming the TASS characteristic data are static over time, we utilize nine different TASS data sets over a period of nine years to use the most accurate characteristic data related to each fund at each time period. We use returns from the most recent TASS data set, however, as they are the most complete and accurate. To control for backfill bias, we remove the first 18 months of returns for each fund. 
${ }^{46}$ Alternative specifications of the canonical analysis are performed, including adjusted returns. These alternative specifications do not change the relationship between operational risk and returns.

${ }^{47}$ The difference in sample size between Panel B and Panel C is due to the fact that average leverage is reported in the TASS database only starting in 2001. Prior to 2001, the data from TASS in the average leverage field was not standardized. Thus, we are only able to run the analysis for five years. This explains the later start year for Panel C (and the resulting increase in average number of funds considered). The style classification developed in Brown and Goetzmann (1997) and applied to hedge funds in Brown and Goetzmann (2003) is likely to err on the conservative side by attributing more leverage effects to style than economically justified. To the extent that higher leveraged funds within a style move more together, this classification will potentially group them as an independent cohort. The advantage is that this approach relies on returns and thus is not biased by any systematic misreporting of style.

${ }^{48}$ See, for example, Sirri and Tufano (1998) or Chevalier and Ellison (1999), who apply this to mutual funds. Agarwal (2006) and Ding (2006) apply this to hedge funds.

${ }^{49}$ The results are robust for this specification of performance. We re-ran the analysis splitting the ranks into four and five groups without any appreciable difference in the results reported in Table IX. Baquero and Verbeek (2006) make the interesting point that lock-up provisions obscure the flow-performance relationship for fund outflows. This is particularly an issue in their study as they are dealing with quarterly flows. According to Lipper TASS, half of the funds they survey in 2007 report that they either maintain a lockup of one quarter or more or assess a significant penalty of between $2 \%$ to $3 \%$ for 
withdrawals before the four-month anniversary of new investment. One would not expect much of a flow outflow on a quarterly basis and it is for this reason that Table IX considers only annual flows. Fund inflows are not subject to lockup provisions, and when we use the Heckman (1979) procedure to estimate the model considering only positive fund flows, we find that the flow performance relationship is stronger and the influence of operational risk is, if anything, weakened. Therefore, the results in Table IX are not an artifact of the lockup provision. We also perform this analysis using the problem dummy and relationship dummy. Although this sample suffers from survivorship bias, the results are similar to the $\omega$-score results we report in Table IX.

${ }^{50}$ The Wall Street Journal, September 29, 2006. 